StOcker, B.A. D., Zinder, N. D. \& LeDERBERG, J. (1953). J.gen. Microbiol.9, 410-433.

\title{
Transduction of Flagellar Characters in Salmonella
}

\author{
By B. A. D. STOCKER* \\ Department of Bacteriology and Immunology, London School of Hygiene and \\ Tropical Medicine, Keppel Street (Gower Street), London, W.C. 1 \\ AND N. D. ZINDER $\uparrow$ AND J. LEDERBERG \\ Department of Genetics, University of Wisconsin, Madison, Wisconsin, U.S.A.
}

SUMMARY: Phage lysates of a salmonella strain can transduce flagellar characters from that strain to a second strain which absorbs the phage. Non-motile strains treated with lysates of other strains produced stable motile forms detected as spreading swarms in semi-solid agar.

$O$ strains of known species produced swarms with the $H$ antigens characteristic of their own species, and the species of previously untypable $O$ isolates could be inferred from the $\mathrm{H}$ antigens of their induced swarms.

The production of swarms by $O$ strains when treated with lysates of other $O$ strains divided nine Salmonella typhimurium $\mathrm{O}$ strains into six interacting groups; there are therefore at least six non-homologous genetic factors, mutation of any of which may cause absence of flagella, thus masking other genes which control $\mathbf{H}$ antigenic specificity.

Two flagellated but non-motile strains produced motile forms when treated with lysates of other strains, or of each other. At least two genes concerned with locomotor function are thus recognized. All the motile derivatives of one $O$ strain spread very slowly through semi-solid agar; the ability to spread rapidly could be transduced to them by a second exposure to a lysate.

In exceptional instances two flagellar characters were simultaneously transduced: three $O$ strains sometimes acquired a flagellar antigen from the donor strain at the same time as the $H$ character; another $O$ strain sometimes acquired simultaneously flagellation and the slow-spreading character.

There are therefore many distinct genes controlling the presence, antigenic character and function of the flagella. They may form part of an ordered gene array in which pairs of genes which are sometimes simultaneously transduced by a single phage particle are presumably closely linked.

Hereditary properties can be transferred or transduced from one salmonella strain to another by the action of cell-free culture filtrates (Zinder \& Lederberg, 1952; Lederberg, Lederberg, Zinder \& Lively, 1951). Filtrates of a salmonella strain lysed by a suitable phage were found to contain an agent which transferred various characters from the lysed (donor) strain to a small proportion of the cells of a recipient strain exposed to the filtrate. As a rule a maximum of only one per million recipient cells acquired a new character, and the simultaneous transfer of two characters from the donor strain to a single cell could not be demonstrated. Cells which had thus acquired a new character by transduction transmitted it to all their progeny through an unlimited number of generations, so far as was tested. The phenomenon is

* Present address : Lister Institute of Preventive Medicine, Chelsea Bridge Road, London, S.W.1.

$\dagger$ Present address : Rockefeller Institute for Medical Research, New York 21, N.Y., U.S.A. 
believed to result from the transference of genetic factors from the donor strain to some cells of the recipient strain. Hereditary changes or transformations of strains of pneumococci and of Haemophilus influenzae may be effected by the action of cell-free lysates of other strains (Griffith, 1928; Alexander \& Leidy, 1951); these changes also are now considered to result from the transfer of genetic material from the lysed strain to the recipient strain. In these organisms the transforming activity of lysates depends on their content of undepolymerized deoxyribonucleic acid, and is destroyed by the action of deoxyribonuclease (Avery, MacLeod \& McCarty, 1944). The transducing activity of salmonella lysates, however, is unaffected by this enzyme, and appears to be associated with the phage particles present in the lysate. It is believed that in salmonella transduction some of the genetic material of a donor cell is incorporated into some of the phage particles which cause its lysis, and that such genetic material is carried by a phage particle into a recipient cell, where it replaces homologous genetic material. The phages concerned neither lyse nor kill a high proportion of cells which absorb them, even in the case of sensitive strains; that is, they are of the kind called temperate (Lwoff, 1953) or symbiotic (Boyd, 1950).

Transduction differs from two other kinds of alteration of the hereditary properties of bacterial strains which may result from exposure to phage, namely the selection of phage-resistant mutants, and the establishment of lysogenicity. In each of these processes strains having new characters, i.e. phage resistance or carriage, and sometimes other correlated characters, are obtained; but the kind of altered strain obtainable is determined only by the phage used, and does not depend on the character of the host on which this phage was grown, as in transduction. The relation of transduction in salmonellas to genetic recombination in Bacterium coli has been discussed by Zinder \& Lederberg (1952) and Lederberg et al. (1951). It must suffice here to recall that recombinants cannot be obtained under conditions which prevent the possibility of cell to cell contact of the two parent strains, that is, filtrates are inactive, and that when the parent strains differ in several characters many of the recombinants obtained derive several characters from each parent strain.

The experiments described in the present paper were designed on the assumption that the transducing activity of filtrates or pasteurized supernatants of salmonella cultures resides in the phage particles which they contain; and they have been interpreted on the premise that the range of characters which a filtrate can transduce is determined by the genetic constitution of the cells in which these phage particles were formed.

The flagella of Salmonellas have been intensively studied, largely because of their importance in the identification of strains pathogenic for man or animals. Some of the available information may be briefly summarized here. All but two species, or serotypes as some authorities prefer, of salmonella normally have flagella, by means of which they are motile. In some environments flagella are not formed, e.g. on media containing phenol (Braun, 1918). Furthermore; strains may undergo spontaneous mutations affecting the presence or abundance of flagella. Non-flagellated variants (known as $O$ 
forms, in distinction from flagellated or $\mathbf{H}$ forms) have frequently arisen in laboratory cultures, and similar strains have been isolated from natural sources. Such $\mathbf{O}$ forms retain the non-flagellated character on subculture, but occasionally produce $\mathrm{H}$ mutants which themselves breed true. $\mathrm{H}$ mutants may be detected and isolated by inoculating the $O$ culture into semi-solid agar, since any motile cells present can spread to parts of this medium inaccessible to non-motile cells, which remain at the site of inoculation. Stable $O$ forms have also been obtained from $\mathbf{H}$ cultures by exposing them to the action of a phage which lyses only flagellated cells (Sertic \& Boulgakov, 1936).

The flagella of salmonellas are efficient antigens, and the species described in the genus are to a large extent differentiated by the antigenic specificity of their flagella. The major antigenic relationships are recorded in the KauffmannWhite schema (Salmonella Sub-Committee, 1949; Kauffmann, 1951). In this schema recognizable flagellar $(H)$ antigens or antigenic 'components' are denoted by the small arabic numerals 1 to 11 , and by small letters from $a$ to $z$ and from $z_{1}$ to $z_{36}$, the $z$ in the $z$-subscript series not denoting any antigenic relationship but merely the exhaustion of the alphabet. Some species have flagella indicated in the schema by several symbols, for instance $g, p, u$ in the case of Sal. rostock. In the present work it has been assumed that such a group of symbols represents the antigenic reactivity of only a single kind of antigen molecule, present in or constituting the flagella of the organism concerned.

Andrewes $(1922,1925)$ showed that in many species of salmonella the flagella may show either of two alternative antigens, and that cells in one 'phase' produce progeny predominantly in that phase but also a proportion of descendents in the opposite phase, which in turn breed true for the most part but produce a proportion of cells in the original phase. The rates of spontaneous change of phase have been measured in Sal. typhimurium and found to be very high, ranging between $9 \times 10^{-4}$ and $10^{-5}$ per bacterium per generation time (Stocker, 1949). Most of the flagellar antigens of the genus fall into two groups, such that the alternative antigens of diphasic organisms include one from each group.

The large number of known antigenic characters, the possibility of selecting either for motility or for the absence of flagella and the extent to which flagellar characters have been investigated make them favourable material for genetic studies. Zinder \& Lederberg (1952) showed that flagellar characters could be transduced, for they were able to replace the characteristic flagellar antigen $d$ of a strain of Sal. typhi by antigen $i$ from a strain of Sal. typhimurium. The present paper describes further investigations of the transduction of various flagellar characters.

\section{METHODS AND MATERIALS}

Phage PLT 22, described by Zinder \& Lederberg (1952), was used for making transducing lysates, and will be referred to in the present paper as phage 22. Brig. J. S. K. Boyd informs us that this phage falls into group A I of his classification of the symbiotic phages of Sal. typhimurium (Boyd, 1950). The host strain used for routine propagation was Sal. typhimurium strain TM2 (strain LT 2 of Zinder \& Lederberg, 1952). 
To obtain a transducing preparation of a salmonella strain, phage 22 was propagated on it in broth, under conditions such as to avoid the inhibition of lysis which occurs when the ratio of added phage to bacteria is high (Boyd, 1951). Broth cultures in which there was at least partial clearing were centrifuged, and the supernate was heated at $60^{\circ}$ for 30 min., to kill all bacteria without affecting the phage. When phage was being grown on a new strain, steps were taken to ensure that the carry-over of inoculum-phage, grown on some other host, was negligibly small. Satisfactory lysates generally gave plaque counts of about $3 \times 10^{9} / \mathrm{ml}$. All phage preparations were tested for sterility, both at the time of preparation and when used.

Table 1. Strains used, characters, and rohence obtained

\begin{tabular}{|c|c|c|c|}
\hline $\begin{array}{c}\text { Our } \\
\text { strain } \\
\text { number }\end{array}$ & Description & $\begin{array}{l}\text { Whence obtained } \\
\text { and donor's strain } \\
\text { number }\end{array}$ & References \\
\hline $\mathbf{T M 2}$ & Sal. typhimurium $\mathbf{H}$ & $\begin{array}{c}\text { Lilleengen, No. } 85=\mathrm{LT2} \\
\text { of Zinder \& Lederberg }\end{array}$ & $\begin{array}{l}\text { Lilleengen (1948), } \\
\text { Zinder \& Lederberg } \\
\text { (1952) }\end{array}$ \\
\hline SW 583 & $\begin{array}{l}\text { Sal. paratyphi-B H (phase } 2 \\
\text { variant of a java strain) }\end{array}$ & Edwards, No. 157 & $\begin{array}{l}\text { Edwards \& Bruner } \\
\text { (1946) }\end{array}$ \\
\hline SW 534 & Sal. paratyphi-B O & $\begin{array}{l}\text { Obtained from SW533 } \\
\text { by action of phage VIII- } \\
113\end{array}$ & $\begin{array}{l}\text { Sertic \& Boulgakov } \\
\text { (1986) }\end{array}$ \\
\hline SW 541 & Salmonella 0 of Group B & $\begin{array}{l}\text { Kauffmann, No. } 223= \\
\text { Cop. } O 1810\end{array}$ & Kauffmann (1947) \\
\hline SW 543 & Sal. paratyphi-B O & $\begin{array}{l}\text { Kauffmann, No. } 248= \\
\text { OB } 19\end{array}$ & Kauffmann (1947) \\
\hline SW 544 & Sal. typhimurium $\mathbf{O}$ & $\begin{array}{l}\text { Schütze, Glasgow O, via } \\
\text { NCTC, 3047; = Strain } \\
\text { OB of Felix }\end{array}$ & $\begin{array}{l}\text { Schütze (1930), Felix } \\
(1930)\end{array}$ \\
\hline SW 545 & Salmonella O of Group B & Edwards, 4937/50 & - \\
\hline SW 548 & Salmonella $\mathbf{O}$ of Group B & Edwards, 2294/49 & - \\
\hline SW 549 & Salmonella O of Group B & Edwards, 117/51 & • \\
\hline SW 553 & Salmonella O of Group D & Edwards, 1520/51 & $\therefore$ \\
\hline SW 578 & Sal. typhimurium 0 & Leifson, $\mathbf{R 2 0} 1 / 2$ & Friewer \& Leifson (1952) \\
\hline SW578 & $\begin{array}{l}\text { Sal. typhimurium non- } \\
\text { motile H strain }\end{array}$ & Leifson, FM 61/63 & Friewer \& Leifson (1952) \\
\hline SW 580 & $\begin{array}{l}\text { Sal. typhimurium non- } \\
\text { motile } \mathbf{H} \text { strain }\end{array}$ & Leifson, FM 59/64 & Friewer \& Leifson (1952) \\
\hline SL13 & $\begin{array}{l}\text { Sal. paratyphi- } A, O \text { variant } \\
\text { of an } \mathrm{H} \text { strain }\end{array}$ & Felix, A17689 (O form) & Felix (1952a) \\
\hline SL15 & Salmonella $O$ of Group B & Taylor, Sal. 1067/52 & - \\
\hline SL 18 & Salmonella $\mathbf{O}$ of Group B & Taylor, Sal. 1565/52 & - \\
\hline SL20 & Salmonella $O$ of Group B & Taylor, Sal. 1878/52 & - \\
\hline SL28 & Salmonella O of Group B & Taylor, Sal. 1775/52 & - \\
\hline SL 47 & Salmonella O of Group B & Taylor, Sal. 2280/52 & . \\
\hline SL 48 & Salmonella O of Group B & Taylor, Sal. 2035/52 & - \\
\hline SL51 & Salmonella $O$ of Group B & Taylor, Sal. 2364/52 & - \\
\hline SL54 & Salmonella $O$ of Group B & Taylor, Sal. 2460/52 & - \\
\hline SL55 & Salmonella $O$ of Group B & Taylor, Sal. 2462/52 & . \\
\hline SL78 & $\begin{array}{l}\text { Sal. typhi, O variant of an } \\
\text { H strain }\end{array}$ & Felix, 0901 & Felix (1930) \\
\hline
\end{tabular}

The strains used are listed in Table 1. Most of the non-flagellated ( 0 ) strains were received from various workers. Other $O$ strains used were non-flagellated mutants which we obtained from $H$ strains by exposure 


\section{B. A. D. Stocker, N. D. Zinder and J. Lederberg}

to phage VIII-113 of Sertic \& Boulgakov (1936); this phage attacks many salmonella strains, but only when they have flagella.

Flagellar and somatic antigens were tested for by slide agglutination, using suitably diluted absorbed sera. All strains of critical importance were submitted either to Dr P. R. Edwards, at the Communicable Disease Center, U.S. Public Health Service, Chamblee, Georgia, or to Dr Joan Taylor, at the Salmonella Reference Laboratory of the Public Health Laboratory Service, Colindale, London, for detailed serological analysis.

To detect the presence of any motile cells in non-motile cultures, arising either by spontaneous mutation or as a result of transduction, loopfuls of broth culture, or the whole of the deposit from a centrifuged culture, were placed on a circumscribed area of the surface of a medium containing $0.4 \%$ agar (Difco) and $8 \%$ gelatin (Difco) in a nutrient broth base (Edwards \& Bruner, 1942). This medium is semi-solid at $37^{\circ}$, so that motile strains spread through it as they grow; but because of its high gelatin content it solidifies at room temperature. To economize materials, this medium was used in $5 \mathrm{~cm}$. Petri dishes, about $10 \mathrm{ml}$. per dish. Inoculated plates were incubated uninverted for $10-18 \mathrm{hr}$, at $37^{\circ}$, allowed to solidify at room temperature and examined for swarms or other evidence of bacterial movement by inspection with a plate microscope and oblique transmitted light. In plates incubated for $10 \mathrm{hr}$. swarms were usually only about $3 \mathrm{~cm}$. in diameter and, if not numerous, were still discrete. But after $18 \mathrm{hr}$. incubation even a single swarm would generally have spread right across the plate.

\section{RESULTS}

\section{Behaviour of untreated non-motile strains grown on semi-solid medium}

The growth of most of the non-motile strains on semi-solid agar was strictly confined to the site of inoculation, even when incubation at $37^{\circ}$ was continued for $48 \mathrm{hr}$. or longer (Pl. 1, fig. I). Some strains, however, gave rise to spontaneous swarms which on subculture were found to consist of stable, motile, $\mathrm{H}$-agglutinable mutants. In many such strains this mutation was a rare event, so that only a few plates showed swarms. In others the mutation was more frequent, so that most or all plates showed spontaneous swarms, but they usually appeared rather late, that is later than the 12th hour of incubation; this presumably indicates that only after several hours of incubation was the population of cells large enough, in relation to the mutation rate, for there to be more than a small probability of a mutation occurring. A few $O$ strains were discarded because of their inconveniently high rate of mutation.

Sal. typhimurium O strain SW545 grew on the surface of the semi-solid medium at the site of inoculation and also produced large numbers of microcolonies, singly or in small groups, $1 \mathrm{~mm}$. or less below the surface of the agar (Pl. 1, fig. 2). Subculture from these colonies yielded only stable $\mathbf{O}$ forms similar to the original strain, and indeed $\mathrm{H}$ mutants have never been obtained from strain SW 545. This phenomenon is being further investigated, but it seems probable that it results from the spontaneous occurrence in this strain 
of a very small fraction of cells which are motile, and therefore migrate through the agar, but which produce only non-motile progeny. Micro-colonies separate from and deep to the site of inoculation have been seen in several other $O$ strains, but in smaller numbers than in SW 545.

The centre, and therefore presumed point of origin, of a swarm was frequently occupied by an area a few millimetres in diameter in which there was a dense crowd of micro-colonies, of diameters inversely related to their distance from the centre of the area. This appearance, which is illustrated in P1. 1, fig. 3, will be termed a 'flare'. Numerous single-colony isolations from flares crowded with micro-colonies always gave stable motile cultures similar to those obtained from the periphery of the swarm, which indicates that the micro-colonies consist of cells which give rise to motile progeny. Flares have also been obtained by inoculating a few cells of certain partly rough motile strains on semi-solid agar. The mechanism of the formation of microcolonies near the point of origin of swarms is not clear; the trapping of motile cells amongst agar fibrils perhaps plays a part, but partial roughness or other physiological or genetic factors which hinder the progression of the initial motile cells may be involved.

The appearance of non-motile strains grown on semi-solid agar has remained constant from experiment to experiment. When a strain was treated with phage 22 propagated on that same strain, the behaviour of the phage-treated cells, as to production of swarms or isolated deep colonies, was exactly the same as that of the untreated culture. This would be predicted if phage in itself has no effect on hereditary properties, such as motility, but can carry across genetic material from its last host; when the genetic material of the last host and the recipient is identical, its transfer from the one to the other will have no detectable effect.

\section{Behaviour of non-motile strains treated with transducing lysates and incubated on semi-solid agar}

In tests for transduction of motility a broth culture of a non-motile strain was incubated with an equal volume of a lysate for $\mathbf{3 0} \mathrm{min}$. to allow phage adsorption. Three loopfuls of the mixture, or the whole of the deposit obtained by centrifuging $1 \mathrm{ml}$. of the mixture, were then placed on semi-solid agar and incubated at $37^{\circ}$ for $10-18 \mathrm{hr}$. The appearances produced when transduction of motility occurred are illustrated in Pl. 1, fig. 4, which may be compared with Pl. 1, fig. 1, which shows the same recipient strain plated without phage treatment. With combinations such as that illustrated, the inoculated area was occupied by dense growth, and surrounded by a wide border of confluent swarming which extended throughout the depth of the agar; when a smaller number of phage-treated cells were inoculated, this continuous border was replaced by discrete swarms (Pl. 1, fig. 5). The centres of the swarms were sometimes marked by flares, as described in the previous section. Unlike spontaneous swarms, these induced swarms were for the most part well developed by the 12th hour of incubation. Subculture from the edge of a swarm always gave a pure growth of motile organisms, and motility was 
retained on further subculture. The growth obtained by subculture from the swarms differed from the parent non-motile strain by its motility and $\mathbf{H}$ agglutinability, and, so far as tested, in no other way, except that it was commonly but not invariably lysogenic for, and resistant to, phage 22 . The occurrence of some colonies of non-lysogenic sensitive cells, which however were motile, indicates that some of the offspring of cells which acquire exogenous hereditary material do not contain descendants of the phage particle which imported the genetic material.

\section{The trail phenomenon in transduction of motility}

Many combinations of phage and recipient non-motile cells produced not only swarms but also groups of micro-colonies deep in the agar and at a distance from the site of inoculation (Pl. 1, fig. 6). These groups were generally more numerous than the swarms, and if the treated cells were appropriately diluted before inoculation, groups of micro-colonies alone were obtained ( $\mathrm{Pl}$. 2, fig. 7). The groups of micro-colonies had an elongated form, the unbranched line about which the colonies were scattered extending from a point in the inoculated area downwards into the agar and laterally for a distance of less than $1 \mathrm{~mm}$. to $20 \mathrm{~mm}$. These linear groups of micro-colonies will be referred to as 'trails'. The number of colonies in a trail varied from 4 to 50, or even more in plates incubated for $48 \mathrm{hr}$. Subculture from these colonies has yielded only non-motile forms, similar to the parent strain; yet the distance of the microcolonies from the site of inoculation, and their position in the depths of the medium, make it clear that the cell from which each colony grew must have reached the site of the colony by active movement. We suggest that trails result from abortive transduction, arising as follows: if a gene carried into an $O$ cell is dominant to that responsible for the absence of flagella, the cell will become motile; but if the exogenous gene fails to replace the homologous gene in the (hypothetical) chromosome, it will not be replicated, so that at cell division there will be produced one cell containing the foreign gene and therefore motile, and one cell lacking it, and therefore non-motile. Thus at any time there will be only one motile cell containing the foreign gene, and its path through the agar will be marked by a trail of micro-colonies growing from the non-motile daughter cells produced each time it divides. Experiments to test this hypothesis are in progress. In this paper only the occurrence of swarms made up of stable motile forms has been recorded as evidence of transduction of motility; however, every combination of lysate and nonmotile recipient strain which, when first tested, produced trails only, has produced swarms when the test has been repeated with larger numbers of treated cells.

\section{Transduction of flagellation to $O$ strains of known species}

In the genus Salmonella, species are distinguished chiefly or entirely by their somatic and flagellar antigens, both flagellar antigenic phases of diphasic organisms being accorded taxonomic weight; some authorities consider that these antigenically differentiated forms should be called serotypes rather than 
species, but in the present paper we have for convenience retained the use of binomials and the designation 'species'. Most of the non-flagellated strains used by us had somatic antigens IV and XII, and thus fell into group B of the Kauffmann-White schema. In this group many species are differentiated solely by their $\mathbf{H}$ antigens, and it might seem that strains lacking flagella could not be assigned to species. However, some of our $\mathbf{O}$ strains were in vitro variants of $H$ strains of known flagellar antigenic constitution, and could be regarded as belonging to the species indicated by the $H$ antigens of their parent strains. Some of these $O$ strains of known species produced spontaneous $\mathbf{H}$ mutants, which in every case resembled the original $\mathrm{H}$ parent both as to the presence or absence of a second phase, and in flagellar antigen or antigens. For instance, we were able to isolate motile mutants from Sal. typhi strain 0901; these $\mathbf{H}$ mutants had flagellar antigen $d$ and were monophasic, like the classical Sal. typhi strain H901 from which Felix and Olitzki isolated the $O$ variant strain in 1925 (Felix, 1930). Strain 0901 has been extensively employed as an $\mathrm{O}$ agglutinogen and for the detection of $\mathrm{O}$ antibodies, and Felix \& Pitt (1951) stated that no reversion to the $\mathbf{H}$ form had then been recorded; our recovery of spontaneous motile variants from it indicates that incubation on semi-solid agar is an extremely sensitive method for detecting motile cells arising in non-motile cultures. Thus at least some $\mathbf{O}$ mutant strains retain the potentiality of producing flagella of the antigenic type characteristic of their parent $\mathbf{H}$ forms; on the gene theory, this indicates the existence of one or more genes determining flagellar antigenic specificity which persist unaltered when the strain ceases to produce flagella, owing to mutation of some other gene.

Some $\mathbf{O}$ strains had been isolated from natural sources as $\mathbf{O}$ forms; some of these produced spontaneous $\mathbf{H}$ mutants, and in view of the findings described above were assigned to the species indicated by the antigens of their $\mathbf{H}$ mutants. In two cases an $\mathrm{O}$ strain had been originally detected as one component in a culture which also contained an $\mathbf{H}$ strain apparently identical with its $\mathbf{O}$ companion except for the presence of flagella; it seemed probable that in each case the $\mathbf{O}$ and $\mathbf{H}$ forms had arisen from a common ancestor, and these $\mathbf{O}$ strains were therefore assigned to the same species as their $\mathbf{H}$ companions.

$A$ number of $\mathrm{O}$ strains having somatic antigen XII, and of known or suspected latent flagellar antigenic formula were thus available. All were treated with phage 22 grown on Sal. typhimurium TM2, and incubated on semi-solid agar; control plates were inoculated with untreated cells. With the exception of Sal. typhimurium $O$ strain SW 573, whose behaviour is discussed later, all the treated strains produced swarms. Some strains also produced spontaneous swarms; but in these strains treatment with the lysate caused an obvious increase in the number of swarms, and the induced swarms appeared earlier than the spontaneous ones. The growth from induced swarms was plated out, and the flagellar antigens of discrete colonies were tested by slide agglutination; alternative phases if not otherwise detected were sought by inoculation into semi-solid agar containing homologous $\mathbf{H}$ antibody. The 
results of these tests are shown in Table 2 , which also records the $\mathbf{H}$ antigens of the related $\mathbf{H}$ strains (parent, mutant or twin component of original mixed culture). It will be seen that every $O$ strain gave induced swarms with the same $\mathbf{H}$ antigenic constitution as its related $\mathrm{H}$ strain(s). Many of the $\mathrm{O}$ strains used were considered to be Sal. typhimurium, that is the same species as the donor strain (TM2). But when the recipient $O$ strain was of some other species, induced motile forms were obtained which had the $H$ antigens believed to be latent in the recipient strain.

Table 2. Salmonella $O$ strains of known species: $H$ antigen $(s)$ of parent $H$ strains, of spontaneous $\boldsymbol{H}$ mutants, and of $\boldsymbol{H}$ forms induced by treatment with $a$ lysate of Sal. typhimurium strain TM2

\begin{tabular}{|c|c|c|c|c|c|c|}
\hline \multirow[b]{2}{*}{$O$ strain } & \multirow[b]{2}{*}{ Species } & \multirow{2}{*}{$\begin{array}{c}H \text { antigen(s) } \\
\text { of parent } \\
H \text { strain }\end{array}$} & \multicolumn{2}{|c|}{$\begin{array}{c}\text { Spontaneous (mutative) } \\
\text { swarms }\end{array}$} & \multicolumn{2}{|c|}{$\begin{array}{l}\text { Swarms induced } \\
\text { by lysate of } \\
\text { strain TM2 }\end{array}$} \\
\hline & & & Rate & $H$ antigens & Number & $\mathbf{H}$ antigen \\
\hline $\begin{array}{l}\text { SW 544 } \\
\text { SW 548 } \\
\text { SW 549 } \\
\text { SW 573 } \\
\text { SL55 }\end{array}$ & $\begin{array}{l}\text { Sal. typhimurium } \\
\text { Sal. typhimurium } \\
\text { Sal. typhimurium } \\
\text { Sal. typhimurium } \\
\text { Sal. typhimurium }\end{array}$ & $\begin{array}{c}\overline{-} \\
\overline{-} \\
i ; 1,2,3\end{array}$ & $\begin{array}{l}\text { Rare } \\
\text { Rare } \\
\text { Common } \\
\text { Nil } \\
\text { Rare }\end{array}$ & $\begin{array}{c}i ; 1,2,3 \\
i ; 1,2,3 \\
i ; 1,2,3 \\
i ; 1,2,3\end{array}$ & $\begin{array}{c}++ \\
++ \\
++ \\
0 \\
++\end{array}$ & $\begin{array}{c}i ; 1,2,3 \\
i ; 1,2,3 \\
i ; 1,2,3 \\
.\end{array}$ \\
\hline SL13 & Sal. paratyphi-A & $a$ & Nil & . & + & \\
\hline SW 543 & $\begin{array}{l}\text { Sal. paratyphi-B } \\
\text { (fixed phase 1) }\end{array}$ & $\boldsymbol{b}$ & Rare & $b$ & ++ & $\left\{\begin{array}{l}b \text { (most) } \\
i \text { (some) }\end{array}\right.$ \\
\hline W 534 & $\begin{array}{l}\text { Sal. paratyphi-B } \\
\text { (fixed phase } 2 \text { ) }\end{array}$ & 1,2 & Common & 1,2 & + & 1,2 \\
\hline L78 & Sal. typhi & $d$ & Common & $d$ & ++ & $d$ \\
\hline
\end{tabular}

$H$ antigens of parent strain ; - indicates strain isolated from natural source as $O$ form. In the case of strains SW543 and SW 573, the $H$ antigens recorded are those of the $H$ component of a mixed culture, i.e. those of the presumed parent strain. Common = spontaneous swarms on most plates incubated for $18 \mathrm{hr}$. Rare=spontaneous swarms on a few plates incubated for $18 \mathrm{hr}$. $\mathrm{Nil}=$ no spontaneous swarms seen in repeated tests.

Thus these $O$ strains when made motile by transduction of flagellation produced $\mathbf{H}$ forms with the $\mathbf{H}$ antigenic constitution known or suspected to be latent in the $\mathbf{O}$ strain, even when it could not be demonstrated by the spontaneous production of $\mathbf{H}$ mutants. The evidence from transduction, therefore, supports the hypothesis that $\mathrm{O}$ strains retain the $\mathrm{H}$-antigen-determining genes of their ancestors, and lack flagella because of some mutation not affecting these genes; the $H$ antigen genes manifest themselves when the flagella reappear, either as a result of a spontaneous mutation of some other gene, or by transduction of some other gene.

The experimental technique used showed that all these $O$ strains when treated with a lysate produced swarms having the $H$ antigenic structure latent in the recipient strain, but did not exclude the possibility that they might in addition produce swarms having $\mathbf{H}$ antigens characteristic of the donor strain on which the transducing phage had been propagated; this could only be detected when donor and recipient strains had different $H$ antigens. Some $O$ strains did in fact produce a minority of swarms with $\mathbf{H}$ antigens character- 
istic not of the recipient $\mathbf{O}$ strain but of the donor strain. This phenomenon is described in detail in a later section; but as in these strains swarms having exogenous $\mathrm{H}$ antigens were always accompanied by an excess of swarms having intrinsic $\mathbf{H}$ antigens, the argument for the presence of $\mathbf{H}$ antigen determinants in $\mathbf{O}$ strains is not invalidated.

\section{Transduction of flagellation to $O$ strains of unknown species}

A number of smooth $\mathrm{O}$ strains were available which had been isolated from nature in pure culture in the $\mathbf{O}$ form, and which did not produce spontaneous H mutants even in repeated tests. Some were Sal. gallinarum or Sal. pullorum, species in which only the $\mathbf{O}$ form is known; these strains were discarded. The others could not be assigned to species. All these strains were treated with a phage 22 lysate of Sal. typhimurium strain TM2; certain strains assigned to group $\mathbf{C}$ of the Kauffmann-White schema were unaffected, presumably because they lacked somatic antigen XII, which is believed to be required for the adsorption of phage 22. All the other $O$ strains tested produced swarms. The motile forms were isolated and their $\mathbf{H}$ antigens determined (Table 3). (In some instances more than one $\mathrm{O}$ strain had been isolated from the same focus of food-poisoning, etc. In such cases all the strains were tested, and related $O$ strains always produced $H$ forms with the same $H$ antigens; but only a single representative of each set has been included in Table 3.) Most of the $\mathrm{O}$ strains produced swarms having $\mathrm{H}$ antigens $i \leftrightarrow 1,2,3$, that is, those found in Sal. typhimurium, the species of the donor strain; others gave swarms having other $\mathbf{H}$ antigens, which, in conjunction with their $\mathbf{O}$ antigens, characterized them as Sal. paratyphi-B, Sal. dublin or Sal. heidelberg. When the derived strain had neither antigen $i$ nor $1, \ldots$, it seemed reasonable to conclude that its $H$ antigen(s) must have been latent in the recipient $O$ strain. When the induced $\mathbf{H}$ form showed antigen(s) also present in the donor strain the evidence was equivocal, since the recipient strain might perhaps have received from the donor strain both an $H$ antigen determinant and a gene for flagella production. The $O$ strains concerned were therefore retested using lysates of various strains having neither antigen $i$ nor antigen $1, \ldots$ In all cases the swarms thus obtained had the same $\mathbf{H}$ antigens as before (Table $\mathbf{3}$ ). The $O$ strains concerned therefore have latent $H$ antigenic constitutions which, with their $\mathbf{O}$ antigens, indicate their species as Sal.typhimurium, Sal. paratyphi-B or Sal. heidelberg respectively.

Although the Salmonella species concerned are defined by their $\mathbf{O}$ and $\mathbf{H}$ antigens, certain other properties show a high degree of correlation. For instance, a phage-typing scheme for Sal. paratyphi-B has been devised (Felix ( Callow, 1943, 1951) and a provisional scheme for Sal. typhimurium is also in use, though it has not yet been published in detail (Felix, 1951). All our O strains of group B were submitted to Dr A. Felix at the Central Enteric Reference Laboratory and Bureau, Colindale, London, and the phage types reported by him are recorded in Table 3. All strains indicated as Sal. paratyphi-B or Sal. typhimurium by their reactions to the typing phages were assigned to the corresponding species by the results of transduction. Two 
strains whose reactions to the phages neither indicated nor excluded diagnosis as Sal. paratyphi-B or Sal. typhimurium were diagnosed Sal. typhimurium and Sal. heidelberg, respectively, by the results of transduction. Strain SL51, diagnosed Sal. paratyphi-B by both methods, was the only strain which produced the 'slime-wall' characteristic of that species. We conclude that the unmasking of latent $\mathbf{H}$ antigens by transduction of flagellation provides a valid method for determining the species of stable $\mathbf{O}$ strains of Salmonella.

Table 3. Salmonella $O$ strains of unknown species: $H$ antigens of swarms induced by lysates of Sal. typhimurium and of Salmonella lacking $\boldsymbol{H}$ antigens $\mathrm{i}$ and $1 . .$. ; reaction to Sal. paratyphi-B and Sal. typhimurium typing phages of Felix \& Callow

\begin{tabular}{|c|c|c|c|c|c|}
\hline \multirow[b]{2}{*}{$\begin{array}{l}\text { Strain } \\
\text { number }\end{array}$} & \multirow[b]{2}{*}{$\mathbf{O}$ antigens } & \multicolumn{2}{|c|}{$\begin{array}{l}\text { H antigens of swarms } \\
\text { induced by lysates of }\end{array}$} & \multirow[b]{2}{*}{$\begin{array}{l}\text { Species indicated } \\
\text { by } O \text { and induced } \\
H \text { antigens }\end{array}$} & \multirow[b]{2}{*}{$\begin{array}{l}\text { Reaction of } O \text { strain } \\
\text { to typing phages }\end{array}$} \\
\hline & & $\begin{array}{l}\text { Sal. typhi- } \\
\text { murium } \\
\text { strain } \\
\text { TM2 }\end{array}$ & $\begin{array}{c}\text { Salmonella } \\
\text { lacking } \mathbf{H} \\
\text { antigens } \\
i \text { and } 1 \ldots\end{array}$ & & \\
\hline $\begin{array}{l}\text { SW 541 } \\
\text { SW 545 }\end{array}$ & $\begin{array}{l}\mathbf{I V}, \mathbf{X I I} \\
\mathbf{I V}, \mathbf{V}, \mathbf{X I I}\end{array}$ & $\begin{array}{l}i ; 1,2,3 \\
i ; 1,2,3\end{array}$ & $\begin{array}{l}i ; 1,2,3 \\
i ; 1,2,3\end{array}$ & $\begin{array}{l}\text { Sal. typhimurium } \\
\text { Sal. typhimurium }\end{array}$ & $\begin{array}{l}\text { Not identifiable } \\
\text { Sal. typhimurium } \\
\text { Type } 2\end{array}$ \\
\hline SL15 & IV, XII & $i ; 1,2,3$ & $i ; 1,2,3$ & Sal. typhimurium & $\begin{array}{l}\text { Sal. typhimurium } \\
\text { Type } 2 a\end{array}$ \\
\hline SL 18 & IV, V, XII & $i ; 1,2,3$ & $i ; 1,2,3$ & Sal. typhimurium & $\begin{array}{l}\text { Sal. typhimurium } \\
\text { Type } 2 a\end{array}$ \\
\hline SL20 & $\mathbf{I V}, \mathbf{V}, \mathbf{X I I}$ & $i ; 1,2,8$ & $i ; 1,2,3$ & Sal. typhimurium & $\begin{array}{l}\text { Sal. typhimurium } \\
\text { Type } 2 a\end{array}$ \\
\hline SL47 & IV, XII & $i ; 1,2, \mathbf{3}$ & $i ; 1,2,3$ & Sal. typhimurium & $\begin{array}{l}\text { Sal. typhimurium } \\
\text { Type } 2 a\end{array}$ \\
\hline SL48 & $\mathbf{I V}, \mathbf{V}, \mathbf{X I I}$ & $i ; 1,2,3$ & $i ; 1,2,3$ & Sal. typhimurium & $\begin{array}{l}\text { Sal. typhimurium } \\
\text { Type } 2 a\end{array}$ \\
\hline SL 54 & IV, V, XII & $i ; 1,2,3$ & $i ; 1,2,3$ & Sal. typhimurium & $\begin{array}{l}\text { Sal. typhimurium } \\
\text { Type } 4\end{array}$ \\
\hline SL51 & IV, V, XII & $b ; 1,2$ & $b ; 1,2$ & Sal. paratyphi-B & $\begin{array}{l}\text { Sal. paratyphi-B } \\
\text { Type } 2\end{array}$ \\
\hline SL28 & IV, V, XII & $r ; 1,2,3$ & $r ; 1,2,3$ & Sal. heidelberg & Not identifiable \\
\hline SW 553 & $\mathbf{I}, \mathbf{I X}, \mathbf{X I I}$ & $\left\{\begin{array}{l}g, p \text { (most) } \\
i \text { (some) }\end{array}\right.$ & & Sal. dublin & \\
\hline
\end{tabular}

The salmonellas lacking antigens $i$ and 1 ... were strains of Sal. abortus-equi (H antigen $e, n, x)$ and Sal. abony (H antigens $b ; e, n, x)$. - indicates test not made. The presence or absence of $O$ antigen $I$ in $O$ strains of group $B$ has not been recorded because of the presence of colonies with and without this antigen within a single strain.

\section{Action of lysates of $O$ strains on other $O$ strains}

If all salmonella $O$ strains (of species which are normally flagellated) lacked flagella from a common cause, that is mutation of the same gene, a lysate of one $\mathbf{O}$ strain would not be expected to confer motility on any other $\mathbf{O}$ strain, for the same reason that an $O$ strain is not made motile by phage grown on itself. But if absence of flagella is due to different causes, that is mutations of non-homologous genes, in different $O$ strains, then an $O$ strain of one kind might produce $H$ forms when treated with a lysate of an $O$ strain of a different kind, for the ineffective determinant in the recipient strain could be replaced 
by its normal homologue from the donor strain. A situation of this sort was found by Zinder \& Lederberg (1952); four galactose-non-fermenting mutants of a strain of Sal. typhimurium fell into two classes, a mutant of one class producing galactose-fermenting papillae when acted on by a lysate of a mutant of the other class, but not when acted on by a lysate of a mutant of its own class.

To seek such interactions, nine O strains of Sal. typhimurium were selected, all of which had been isolated from natural sources as $\mathbf{O}$ forms; where several $O$ strains had been isolated at the same place and time, only one from each set was included in the experiment. Lysates having been made from all of the strains which were sensitive to phage 22 , strains and lysates were tested in all possible combinations, and plated on semi-solid agar; sterility controls on the lysates, and control plates of untreated recipient cells were included in the tests, and the $\mathbf{H}$ antigens of all swarms obtained were checked. Combinations not yielding swarms at the first attempt were tested again, using treated cells concentrated by centrifugation.

Table 4. Action of lysates of Sal. typhimurium $O$ strains on Sal. typhimurium $O$ strains

\begin{tabular}{|c|c|c|c|c|c|c|c|c|c|c|c|}
\hline \multirow{2}{*}{$\begin{array}{c}\text { Cells } \\
\text { of Sal. } \\
\text { typhi- } \\
\text { murium } \\
\text { O strain }\end{array}$} & \multicolumn{9}{|c|}{ Lysate of Sal. typhimurium O strain } & \multirow{2}{*}{$\begin{array}{c}\text { Lysate } \\
\text { of Sal. } \\
\text { typhi- } \\
\text { murium } \\
\text { H strain } \\
\text { TM2 }\end{array}$} & \multirow{2}{*}{$\begin{array}{l}\text { Control } \\
\text { (no } \\
\text { lysate) }\end{array}$} \\
\hline & $\begin{array}{l}\text { SW } \\
541\end{array}$ & $\begin{array}{l}\text { SW } \\
544\end{array}$ & $\begin{array}{l}\text { SW } \\
545\end{array}$ & $\begin{array}{l}\text { SW } \\
548\end{array}$ & $\begin{array}{l}\text { SW } \\
549\end{array}$ & $\begin{array}{l}\text { SW } \\
573\end{array}$ & $\begin{array}{l}\text { SL } \\
15\end{array}$ & $\begin{array}{l}\text { SL } \\
18\end{array}$ & $\begin{array}{l}\text { SL } \\
20\end{array}$ & & \\
\hline SW 541 & $\mathbf{0}$ & + & - & - & + & + & + & + & + & + & $\mathbf{0}$ \\
\hline SW 544 & $\mathbf{S}$ & $\mathbf{0}$ & - & - & $\mathbf{S}$ & $\mathbf{S}$ & $\mathbf{S}$ & $\mathbf{S}$ & $\mathbf{S}$ & $\mathbf{S}$ & $\mathbf{0}$ \\
\hline SW 545 & + & + & - & - & + & + & + & + & + & + & $\mathbf{0}$ \\
\hline SW548 & + & $+\& S$ & - & - & + & + & + & + & + & + & $\mathbf{0}$ \\
\hline SW 549 & + & + & - & - & $0(+)$ & + & + & + & + & + & $\mathbf{o}(+)$ \\
\hline SW 573 & 0 & 0 & - & - & 0 & 0 & 0 & 0 & 0 & 0 & 0 \\
\hline SL15 & + & + & - & - & + & + & $\mathbf{0}$ & $\mathbf{0}$ & $\mathbf{0}$ & + & $\mathbf{0}$ \\
\hline SL 18 & + & + & - & - & + & + & $\mathbf{0}$ & $\mathbf{0}$ & $\mathbf{0}$ & + & $\mathbf{0}$ \\
\hline SL20 & + & + & - & - & + & + & $\mathbf{0}$ & $\mathbf{0}$ & $\mathbf{0}$ & + & 0 \\
\hline
\end{tabular}

+ , rapid-spreading swarms; $S$, slow-spreading swarms; 0 , no swarms; $0(+)$, swarms after long incubation only; - , test not made because lysate not available.

The results of this experiment are shown in Table 4. Seven of the strains fall into five groups, one group comprising three strains, the others one strain each, strains within a group being inactive on each other but active on strains of all other groups. The remaining two strains, SW 545 and SW 548, do not fall into any of the five groups defined above; they cannot be tested for action on each other, since neither can be lysed by phage 22. Where pairs of strains could be tested for interaction in each direction, the reciprocal tests gave consistent results, except that strain SW 573 was unaffected by lysates of strains which themselves responded to a lysate of strain SW 573. However, strain SW 573 also fails to respond to treatment with lysates of $H$ strains, so that its unresponsiveness to treatment with $O$ strains was to be expected. A possible explanation for its behaviour is proposed later.

This experiment shows that there are at least six different classes of 


\section{$422 \quad$ B. A. D. Stocker, N. D. Zinder and J. Lederberg}

O strains of Sal.typhimurium, and therefore that there are at least six genetic factors, mutation of any one of which may cause loss of flagella. The existence of so many different genes all apparently concerned in the production of flagella may seem surprising, but there are many parallels in the genetics of other organisms. One may instance seven loci in Bact. coli strain K12, mutation at any one of which may result in failure to ferment lactose (Lederberg et al. 1951), or the seventy-three factors controlling chloroplast development in maize cited by de Haan (1938).

Strains SL15, SL18 and SL 20 failed to interact in any of their possible combinations, and two Sal. typhimurium $\mathrm{O}$ strains received later (SL 47 and SL 48), also fall into the same group. All five strains were isolated from cases of human infection in various parts of England during 1952. These five $O$ strains might represent repeated isolations of a single $O$ strain widely distributed in England during 1952, or they might have resulted from independently occurring mutations affecting homologous genes in different $\mathbf{H}$ strains. It was therefore of interest to investigate the strains by other techniques which might tend to indicate or exclude a common origin. The results of antigenic analysis by Dr Taylor were available, and the strains were also submitted to Dr Felix for phage-typing, and to Brig. Boyd for identification of the phages (if any) carried by them (Boyd, Parker \& Mair, 1951). The phage-typing results are compatible with a recent common origin, for all five strains gave the reactions of Sal. typhimurium Type $2 a$. The $\mathrm{O}$ antigens and the lysogenicity findings divide the strains into two groups. Three strains have antigen V (antigen B Vi of Felix, 1952b), and carry phages A2 and B2; the other two strains do not possess antigen $\mathrm{V}$ (in amounts detectable by agglutination tests) and carry phage $\mathbf{B 2}$ only. This evidence is not unequivocal, for the isolation of both $\mathrm{V}$-positive and $\mathrm{V}$-negative strains from the same patient (Kauffmann, 1934) suggests that antigen $V$ may appear or disappear by mutation; and strains may be made lysogenic for phage A2 in the laboratory, and presumably therefore this may also occur in nature. It is therefore uncertain whether all the $\mathbf{O}$ strains of this group derived from a common $O$ ancestor, or whether they have arisen on two or more occasions by mutations perhaps affecting the same gene.

The high frequency with which lysates of $O$ strains render motile other $O$ strains might suggest that the production of $\mathbf{H}$ forms under these conditions is not dependent on the transfer of genetic material from the lysed strain, as has been argued above, but is a consequence of exposure of an $O$ strain to phage 22 grown on any heterologous host. However, phage grown on a spontaneous $H$ mutant of $O$ strain SW 543 evoked numerous swarms from its parent $\mathbf{O}$ strain. Similarly, a lysate of an induced $\mathbf{H}$ form obtained from $\mathbf{O}$ strain SL 15 evoked swarms from its parent $O$ strain. In each case a lysate of the $O$ strain itself had no effect. Tests with other $O$ strains and their spontaneous or induced $\mathbf{H}$ derivatives have given similar results. Each of these $\mathbf{H}$ derivatives, so far as we know, differed from its $\mathrm{O}$ parent only by the presence of flagella, and of the gene determining this; but phage grown on the $\mathrm{H}$ derivative could confer motility on the $O$ parent. Thus motility may result 
from exposure of an 0 strain to phage grown on a strain which is not an unrelated strain, provided that it possesses the gene which is deficient in the recipient $\mathbf{O}$ strain.

\section{Flagellar antigenic phase latent in cells of $O$ strains}

Motile forms of Sal. typhimurium, obtained from $\mathbf{O}$ strains by transduction, underwent diphasic flagellar variation exactly as do normal $\mathbf{H}$ cultures of $\boldsymbol{S a l}$. typhimurium. The first culture from any one swarm gave growth which was agglutinated strongly by antiserum for one of the two $\mathbf{H}$ antigens, weakly or not at all by antiserum for the other; that is, the swarm was (predominantly) in one phase. The phase of induced swarms was determined by the recipient $O$ culture, and not by the inducing lysate. This was demonstrated by treating single colony broth cultures of $O$ strains with lysates of a number of different strains. In each such experiment all or nearly all of the swarms resulting from transduction (or arising by spontaneous mutation) proved to be in one and the same flagellar phase, even when the lysate used was made from an $\mathbf{H}$ strain known to have been almost entirely in the opposite phase at the time of lysis. A single colony broth culture, as used in these experiments, would have been derived from one cell by a small number of generations, and would therefore be nearly homogeneous, even for a character which, like flagellar antigenic phase, commonly mutates at a very high rate (Stocker, 1949). Cells of an $\mathbf{O}$ strain may then be considered to be in one flagellar antigenic phase or the other, though this character is unexpressed in the absence of flagella.

\section{Experiments on non-motile flagellated (' paralysed') strains}

All motile salmonella strains have flagella, but several non-motile flagellated strains have been reported (Colquhoun \& Kirkpatrick, 1932; Kauffmann, 1939; Edwards, Moran \& Bruner, 1946; Hirsch, 1947; Friewer \& Leifson, 1952). Hirsch's strain of Sal. paratyphi-B and Friewer \& Leifson's strain of Sal. typhimurium had morphologically typical flagella, were $\mathrm{H}$-agglutinable, and showed flagellar antigenic phase variation, but were non-motile under all conditions tested, as judged both by microscopy and by the absence of spreading growth in semi-solid media.

We received from Dr Leifson two non-motile $H$ strains, labelled by us SW 578 and SW 580, and an $O$ strain, our SW 573; the $O$ strain and one of the non-motile $H$ strains (SW 580) had been derived from single $O$ and $H$ colonies respectively, picked from the original plating of a salmonella culture submitted for identification; this primary culture also yielded colonies of normal motile flagellated Sal. typhimurium. The non-motile H strain SW 580 had produced by mutation a motile variant; and from this motile substrain after several subcultures Leifson had selected colonies of a new non-motile $\mathbf{H}$ form, our strain SW 578. Thus the two non-motile $\mathrm{H}$ strains, though derived from a common ancestor, were not necessarily genetically identical, for $\mathrm{SW} 580$ was isolated as a non-motile $H$ form, whereas SW 578 originated from a motile strain by mutation in vitro.

These two non-motile $H$ strains when incubated on semi-solid agar at $37^{\circ}$ 


\section{$424 \quad B . A$. D. Stocker, N.D. Zinder and J. Lederberg}

behaved exactly as did $O$ strains; their growth was strictly confined to the site of inoculation, except for the occasional mutative production of isolated swarms. Each produced large numbers of swarms when treated with a lysate of Sal. typhimurium strain TM2. Thus motility can be transduced to nonmotile $\mathbf{H}$ strains in the same way that flagellation (and resultant motility) can be transduced to $O$ strains.

Lysates were made from both non-motile $H$ strains; various $O$ strains treated with either of these lysates produced swarms; this indicates that the 'paralysed' strains contain the normal homologues of the various mutant genes responsible for the absence of flagella in these $O$ strains. Each of the non-motile $\mathbf{H}$ strains produced swarms when treated with a lysate of the other, but was unaffected by a lysate of itself. As in the case of the interactions of $\boldsymbol{O}$ strains, this indicates that the two strains are non-motile through different causes, i.e. mutation of non-homologous genes. The history of the strains made it clear that the lack of motility of the two strains did not result from a single mutational event, so that their genetical non-identity is less surprising than it at first seemed.

Strain SW 573, the $O$ strain isolated from the same primary culture as the non-motile H strain SW 580, was the only Sal. typhimurium $\mathrm{O}$ strain studied which did not readily produce swarms when treated with lysates of other $S a l$. typhimurium strains, whether $\mathbf{H}$ or $\mathbf{O}$. The history of this culture suggests that mutation causing loss of motility without loss of flagella occurred not infrequently in it; and a possible explanation for the failure of SW 573 to produce motile swarms by transduction would be that it arose from a normal motile $\mathbf{H}$ strain by two successive mutations, one causing non-motility without loss of flagella, and the other causing loss of flagella. If, as seems likely, these mutations affected separate genes, the strain could only become motile by alteration of two genes, and Zinder \& Lederberg (1952) found that in transduction no one cell could be shown to acquire more than a single new gene. Neither of the two forms theoretically obtainable from SW 573 by transduction of a single gene would be motile. This explanation for the failure of $O$ strain SW 573 to produce swarms has been confirmed by the isolation from it of a non-motile $H$ variant. In attempts to obtain swarms from SW 573 by transduction, using lysates of various strains, repeated platings of treated cells did finally produce swarms in two instances, and in the course of these experiments a few trails were also found; on the hypothesis proposed earlier, the colonies making up a trail consist of progeny of a cell made motile by transduction, but which have themselves reverted to their original (non-motile) genetic condition. Colonies from two trails, produced by SW 573 treated with lysates of $O$ strains SW 544 and SL 18 respectively, were subcultured; they yielded apparently pure growth of non-motile $\mathbf{H}$ forms. This finding is taken to indicate that even single-colony broth cultures of strain SW573 contain a small proportion of cells which have acquired flagella by mutation, but which remain non-motile because of a 'paralysis' gene. This small fraction of mutant $H$ cells can become motile by alteration of a single gene, and transduction affecting this small minority of mutant cells would account for the rare trails and swarms. 


\section{Experiments on slow-swarming strains}

The behaviour of Sal. typhimurium O strain SW 544, when treated with lysates, differed from that of all the other $O$ strains of this species which we investigated; after about $12 \mathrm{hr}$. incubation at $37^{\circ}$, other strains produced swarms which, when discrete, were several centimetres in diameter, whereas the swarms produced by SW 544 under similar conditions were only a few millimetres in diameter (Pl. 2, fig. 8). Subculture of these slow-spreading swarms gave colonies of motile flagellated organisms, which retained the character of spreading slowly in semi-solid medium. It is not clear why these strains spread slowly, since in broth, at room temperature or at $37^{\circ}$, they appear about as motile as fast-spreading strains, both as to proportion of motile cells and in rate of movement; nor do they differ from other motile strains in flagellar morphology or H-agglutinability. Strain SW 544 sometimes produced spontaneous swarms; these also were of the slow-spreading kind. The slow-swarming character of motile derivatives of strain SW 544 was fairly stable; after $12 \mathrm{hr}$. incubation on semi-solid agar, the site of inoculation was surrounded by a border of dense growth a few millimetres wide, resulting from the slow spread of the culture as a whole; a few rapid-spreading swarms were usually also present, evidently resulting from mutation (Pl. 2, fig. 9). As these spontaneous rapid-spreading swarms were few in number, it was possible to test whether the rapid-swarming character of other strains could be transduced to the slow spreaders. A slow-spreading $\mathbf{H}$ mutant of 'strain SW 544 was treated with lysates of various $H$ and $O$ strains; this treatment caused the appearance of numerous fast-spreading swarms. Cells treated with lysates of the slow-spreading strain itself, or of its $O$ parent strain, SW 544, produced no more fast-spreading swarms than did control untreated cells. It is concluded that the character of slow swarming is latent in strain SW 544, though unexpressed because of the absence of flagella; that the homologous gene present in rapid-swarming strains can be transduced by phage; and that the gene concerned with the slow- or rapid-swarming character is not the same as that which determines the lack of flagella in strain SW 544.

SW 544 is our label for strain 'Glasgow $O$ ' of Schütze (1930), also known as strain OB (Felix, 1930). Schütze isolated it from the liver of a rat inoculated 3 months before with an $\mathbf{H}$ strain of Sal. typhimurium, strain 'Glasgow H', and as its somatic antigens were the same as those of the inoculated $H$ strain he regarded it as an $O$ variant of strain Glasgow $H$. We obtained strain Glasgow H (NCTC 3048) from the National Collection of Type Cultures, where it had been deposited by Schütze in 1929 , to see whether it showed the slowspreading character found in all the motile derivatives of strain Glasgow $O$ (SW 544). Contrary to our expectation, strain Glasgow H spread through semi-solid medium with normal rapidity. The circumstances of its isolation suggested to us that strain Glasgow $O$ might have been an independent salmonella $O$ strain acquired by the rat through natural infection, rather than an $\mathbf{O}$ mutant of strain Glasgow $\mathrm{H}$, which would account for the absence of the slow-spreading character in the latter strain. This suspicion was confirmed by 
the results of phage-typing by $\mathrm{Dr}$ Felix, for strain Glasgow $O$ gave the reactions of Sal. typhimurium Type $1 a$, whereas strain Glasgow $\mathrm{H}$ reacted as Type 1b. Although the parentage of strain Glasgow $O$ (SW 544) is thus unknown, its identification as Sal. typhimurium is established by the flagellar antigens of its spontaneous $\mathrm{H}$ mutants and the $\mathrm{H}$ forms obtained from it by transduction, and also by the results of phage-typing.

\section{Simultaneous transduction of two flagellar characters}

In previous experiments (Zinder \& Lederberg, 1952), a single exposure to a lysate never resulted in the appearance of cells which had simultaneously acquired more than one new trait, even when the lysate transduced several different characters, one at a time, to different cells of the treated suspension; that is no one cell was shown to acquire more than one of the genes determining the differences between the strains. In the present work, several examples of the simultaneous transduction of two characters have been encountered; in each case both the characters transferred together relate to bacterial motility.

The two examples first met consist in the simultaneous acquisition by an $\mathbf{O}$ strain of the ability to produce flagella, and of a new flagellar antigen. The strains concerned were SW 543, an O strain of Sal. paratyphi-B, and SL 13, an O strain of Sal. paratyphi-A. SW 54,3 was received from Dr F. Kauffmann, who had found it as one component of a culture which also contained a flagellated but otherwise similar strain with $\mathbf{H}$ antigen $b$; as no second phase could be obtained from the $\mathbf{H}$ component, the culture was considered to be one of Sal. paratyphi-B fixed in the specific phase. Similar monophasic $\mathbf{H}$ forms with flagellar antigen $b$ have been obtained from the $O$ component, SW 543, by mutation. The other $O$ strain concerned, SL 13, was an $O$ variant isolated by $\mathrm{Dr}$ Felix from an $\mathrm{H}$ strain of $S a l$. paratyphi-A of typical antigenic constitution, that is with only a single phase and flagellar antigen $a$.

When these $\mathbf{O}$ strains were treated with lysates of Sal. typhimurium strain TM2 most of the swarms which they produced had the $\mathbf{H}$ antigen characteristic of the recipient strain, that is $b$ or $a$ respectively; as these antigens are not found in the donor strain we conclude that these $O$ strains retain the potentiality of producing their characteristic flagellar antigens, and this potentiality we presume is located in a gene (or genes). In addition, both strains produced a minority of swarms with flagellar antigen $i$, an antigen present in the donor strain, but not latent in the recipient $O$ strains (so far as can be tested). These derivatives with an exogenous $\mathbf{H}$ antigen, like those with the intrinsic antigens $b$ or $a$, were monophasic. The simplest hypothesis to account for these findings is that each of these $O$ strains contains a mutated gene determining the absence of flagella and another gene which determines the antigenic composition of the flagella when present, and that the donor strain of Sal. typhimurium contains homologous genes, one of which determines the $\mathbf{H}$ antigenic constitution of Sal. typhimurium in the specific phase, that is antigen $i$. The transfer of one only of these genes would result in $\mathbf{H}$ cells with the flagellar antigen characteristic of the recipient strain, the transfer of both would result 
in $\mathbf{H}$ cells having antigen $i$. The genetic basis of these coupled transductions is being studied further, but two lines of evidence lend support to the above interpretation.

The two O strains SW543 and SL13 have been exposed to lysates of salmonellas other than Sal. typhimurium, and in every case when swarms were produced a minority of them had an $\mathbf{H}$ antigen characteristic of the lysed strain. Thus SW 543 treated with lysates of Sal. sendai, Sal. altendorf and Sal. heidelberg produced swarms, a minority of which were monophasic $\mathbf{H}$ forms with flagellar antigens $a, c$ and $r$ respectively. In each case the 'partial hybrid' had the same $\mathbf{O}$ antigenic constitution as the $\mathbf{O}$ parent strain, that is IV, V, XII. Similarly, strain SL 13 treated with a lysate of Sal. heidelberg produced swarms most of which had the antigenic constitution I, II, XII: $a$; -, and a few which were I, II, XII: $r$; -. Several of these antigenic combinations have not been reported in naturally occurring Salmonella spp., and such monophasic $\mathbf{H}$ forms may be of value for the production of diagnostic serological reagents (cf. Edwards \& Bruner, 1946).

Sal. paratyphi $B$ O strain SW 543, treated with a lysate of Sal. typhimurium, produced two kinds of swarms, $b$ and $i$, and we attribute the latter kind to the simultaneous transfer of two genes. An alternative hypothesis postulates that strain SW 543 lacks flagella through the presence of a 'suppressor' gene with the property of preventing the development of flagella of antigenic type $b$, but not of flagella of other antigenic types. Transduction of the normal homologue of the suppressor gene, from Sal. typhimurium, would then result in $b$ swarms; transduction of the determinant for $\mathbf{H}$ antigen would result in $i$ swarms. This hypothesis requires only single gene transductions. However, it is excluded by the results of experiments on the transducing activity of lysates of the $i$ swarms obtained from strain SW 543 by exposure to lysates of Sal. typhimurium. Such lysates provoke both $b$ and $i$ swarms from their parent 0 strain, SW 543, as would be expected on our hypothesis that the $i$ swarms resulted from the simultaneous transfer of two genes. On the alternative hypothesis of a 'suppressor' gene and single gene transfers only, the $i$ derivatives of strain SW 543 would retain the gene suppressing the development of $b$ flagella, and lysates of them would therefore be unable to provoke $b$ swarms from SW 543, which ex hypothesi also carries the $b$ suppressor gene.

Retesting of our other O strains has shown that Sal. dublin $\mathrm{O}$ strain SW 553 also produces a minority of swarms with an $\mathbf{H}$ antigen characteristic of the donor strain, instead of antigen $g, p$ known to be latent in SW 553. No further examples of double transduction of this kind have been found, even when they were selected for by plating $O$ cells on semi-solid agar containing antibody for their latent $H$ antigens, but not for the $H$ antigens of the donor strain. It appears then that the ' $O$ ' genes which determine absence of flagella in strains SW 543, SL13 and SW 553 are related to a gene which determines flagellar antigenic specificity, in such a way that when the ' $O$ ' gene is replaced by its normal homologue from another strain, the gene for the intrinsic $\mathbf{H}$ antigen $(b, a$, or $g, p)$ is frequently also replaced by a homologous gene determining a flagellar antigen of the donor strain. Experiments 
intended to test the homology of the genes causing absence of flagella in strains SW 543, SL 13 and SW 553 are in progress.

What is probably a further case of simultaneous transfer of two characters was met in the course of testing $\mathbf{O}$ strains for interaction. Sal. typhimurium $\mathbf{O}$ strain SW 548 when it acquired motility, by mutation or through transduction from strains other than SW 544, produced only fast-spreading swarms; but when treated with a lysate of SW 54,4 it produced some fast and some slow swarms (Pl. 2, fig. 10). Strain SW 544 (Glasgow O) though it lacks flagella is known to carry the slow-swarming character, and the slow-swarming $\mathbf{H}$ forms obtained from SW 548 by treatment with lysates of SW 544 resembled the slow-swarmers which the latter strain produces when it acquires the $\mathbf{H}$ character by mutation or transduction. The fast-spreading swarms obtained from $O$ strain SW 548 by the action of lysates of SW 544 may be explained by the transfer from SW 544 of a single gene, i.e. the normal homologue of the gene determining the $O$ state of SW 548. The slow swarms produced by the same treatment we think result from the simultaneous acquisition by some cells of a second gene, the 'slow-swarming' gene of strain SW 544. Our investigation of this case has been limited by our inability to test the action of lysates of SW 548 and its $\mathbf{H}$ derivatives, for they are all resistant to phage 22. An alternative but perhaps less probable explanation involving a 'suppressor' gene therefore cannot be tested. No other $O$ strain has been observed to acquire the slow-swarming character when it acquires motility by treatment with a lysate of strain SW 544. On the simultaneous transduction hypothesis it appears that the gene determining the absence of flagella in strain SW 548 is related to a gene which determines slow or rapid spreading in such a way that when one is replaced by transduction so often is the other; but that the (non-homologous) genes determining absence of flagella in the other $\mathbf{O}$ strains are not so related to the 'speed of swarming' gene.

\section{DISCUSSION \\ Genetics of flagellar characters in salmonellas}

The experiments described show that various flagellar character may be conferred on salmonella strains by transduction from other strains; flagellation has been transduced to $\mathrm{O}$ strains, motility to non-motile $\mathrm{H}$ strains, and the rapid-swarming character to slow-swarming strains. Since in general only one character has been transferred at a time the transducing activity of lysates must be localized in material particles of different kinds, i.e. having different genetic effects; and these particles must have come from the cells which were lysed. As the characters conferred are retained on subculture, the material which confers a new character must be replicated and transmitted to all the progeny of the cell which acquires it. Thus these experiments support the hypothesis that there is in salmonellas specialized material determining, in part at least, the hereditary properties of the organism, and that this material is divisible into qualitatively different localized units concerned with the control of different characters; that is, the hypothesis that salmonellas, like other organisms, have genes. 
The experiments on transduction of flagellation to $\mathrm{O}$ strains by treatment with lysates of other $O$ strains show the existence of a number of different genes, mutation of any one of which may cause absence of flagella. Latent $\mathbf{H}$ antigens were demonstrated in all the $\mathrm{O}$ strains tested. One may compare the retention of latent $H$ antigens by $O$ strains with the behaviour of $H$ strains grown under conditions such that flagella are not formed, e.g. on phenol agar. In each case cells without flagella retain and transmit the ability to form a particular $\mathbf{H}$ antigen when flagella are produced, i.e. after mutation or transduction of the $\mathbf{H}$ character in the one case, or on transfer to a suitable medium in the other. On the gene theory this ability is localized in a gene or genes regulating $H$ antigen specificity.

The experiments on non-motile $\mathbf{H}$ strains and on slow-swarming strains show the existence of several genes concerned with flagellar function. So far as they have been investigated, these genes seem to be different from each other, from the genes determining $\mathrm{H}$ antigenic specificity, and from those determining the presence or absence of flagella. Lewin (1952) has reported comparable genes controlling flagellar function in the green alga Chlamydomonas moerousii.

The experiments so far discussed indicate the existence of a number of different genes concerned with various flagellar characters, but do not indicate how these genes are arranged in the cell. Some inferences as to this may be drawn from the exceptional instances of simultaneous transduction of two characters. In each instance there is a relationship between the members of a particular pair of genes such that cells which acquire one of the pair by transduction frequently acquire the other also. If in salmonellas the genes are arranged in a constant ordered array, it may be that in transduction genes which are close together in the array will sometimes be carried over together in a single fragment of the gene array. On this hypothesis the genes which can be simultaneously transduced would be genes adjacent to each other in the array. In all organisms whose genetics have been extensively investigated the genes behave as if arranged in linear groups, which correspond to microscopically demonstrable chromosomes; one may suppose that in salmonellas also the postulated gene array consists of one or more linear groups.

It is noteworthy that in each of the instances of simultaneous transduction so far observed, both the characters transferred together have related to the same organelle, i.e. flagella. Experiments intended to reveal the simultaneous transduction of pairs of unrelated metabolic characters (Zinder \& Lederberg, 1952), or of a metabolic character (xylose or galactose fermentation) and of flagellation to an $\mathrm{O}$ strain, have given negative results. One may speculate on the possibility that pairs of salmonella genes which can be transduced together correspond to the groups of very closely linked loci all concerned with the same character or function which are familiar in the genetics of other organisms, e.g. the closely linked $\mathrm{Lac}_{1 a}, \mathrm{Lac}_{1 b}$ and $\mathrm{Lac}_{4}$ loci of Bact. coli $\mathrm{K} 12$, mutation at any of which leads to failure to ferment lactose (Lederberg, 1952). 


\section{The phenomenon of transduction}

All the experiments here described have been compatible with the hypothesis (Zinder \& Lederberg, 1952) that transduction of characters in salmonellas results from transference of genetic material by phage particles from the cells in which they were formed to cells which absorb the phage. Some new observations on the process have been made. The detection of some motile but non-lysogenic cells in induced swarms has shown that phage is not always transmitted to all the progeny of cells showing a transduced character. This divorce of transducing phage from transduced character has also been seen in the transduction of other characters, e.g. the ability to ferment galactose. The trail phenomenon in the transduction of motility suggests that phageimported genetic material which modifies the character of the cell containing it sometimes fails to replace the homologous genetic material of the recipient cell, and therefore fails to be replicated. The simultaneous transduction of two characters to a single cell has been demonstrated for the first time. In each instance observed, both characters have related to flagella, but have been shown to be determined by separate genes. This suggests that in transduction the genetic material carried over consists not of units of the smallest possible size, but of small fragments of a genetic structure, perhaps short pieces of chromosome.

The present work emphasizes the relationship between transduction of characters in Salmonella spp. and the phenomena of genetic transfer in pneumococcus and $\boldsymbol{H}$. influenzae termed 'transformation'. The vector of transduction in salmonellas appears to be a phage particle, whereas the agent concerned in the other genera has the properties of undepolymerized deoxyribonucleic acid; but genetically the phenomena are very similar. In both systems the characters which the active agent can confer are determined by the hereditary properties of the strain from which it was obtained. The production of flagellated forms by salmonella $O$ strains treated with lysates of other $O$ strains is formally similar to what has been termed 'allogenic transformation' of pneumococci, that is the production by a transformation reaction of a pneumococcal strain showing a character (presence of capsules of normal size) not shown by either the recipient strain or the donor strain from which the transforming agent was extracted (Ephrussi-Taylor, 1951 $a, b$ ); the explanation proposed for allogenic transformation by Ephrussi-Taylor is not essentially different from that suggested for the analogous phenomenon in salmonellas, namely, that the character is only expressed when two different genetic factors are both present together in the cell.

A difference between comparable cases of transference of characters in the two groups is the retention of (latent) flagellar antigenic specificity by all nonflagellated salmonellas mutants, and the apparent absence of latent capsular antigenic specificity in some non-encapsulated mutants of pneumococci and $H$. influenzae; for the latter when transformed to encapsulation by transforming agent obtained from heterologous strains produce capsules whose antigenic specificity is that of the donor strain. We take this to indicate that 
Journal of General Microbiology, Vol. 9, No. 3
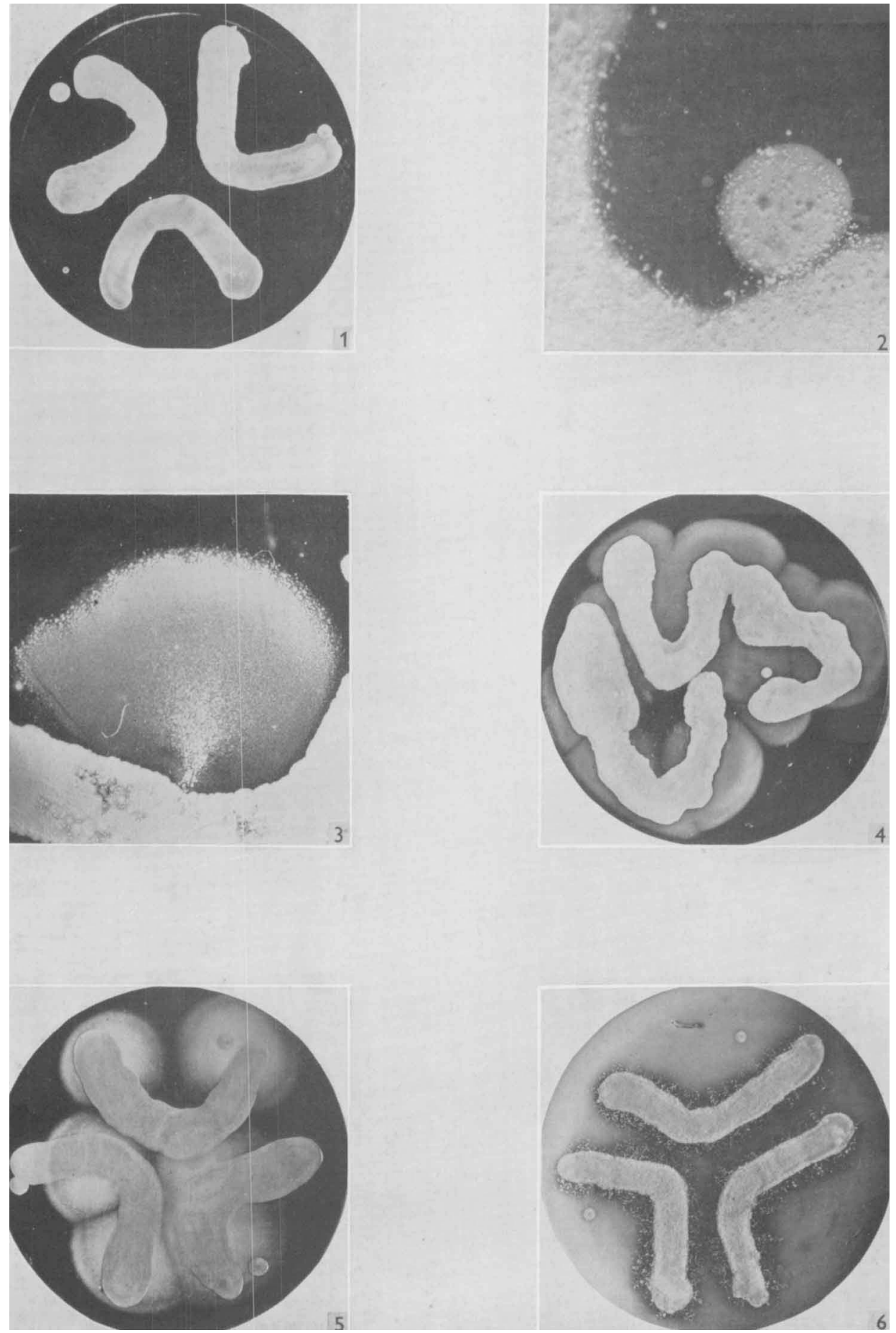

3. A. D. Stocker et al.--Transduction of flagellar characters. Plate 1 
Journal of General Microbiology, Vol. 9, No. 3

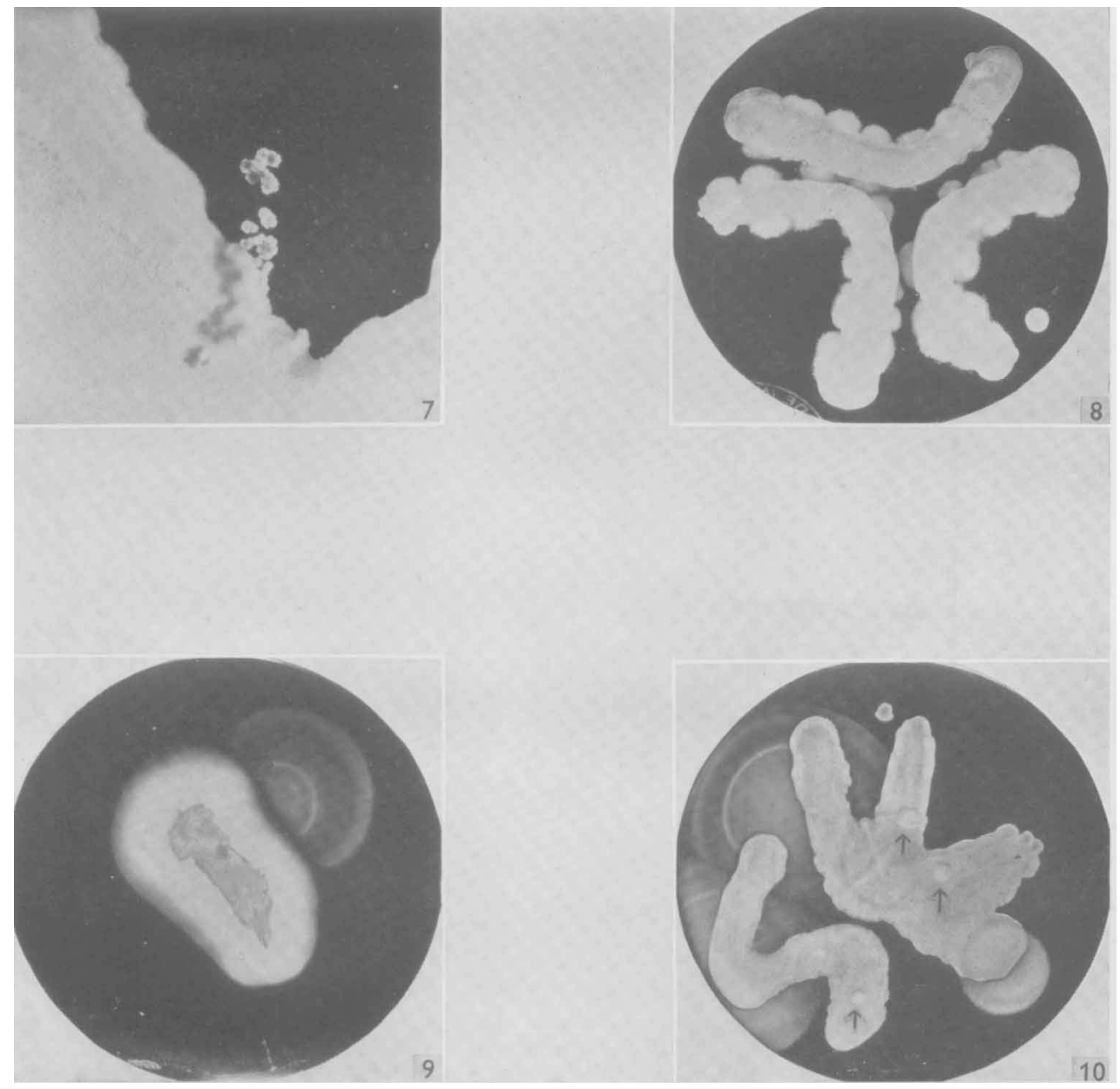

B. A. D. Stocker et al.-Transduction of flagellar characters. Plate 2 
the strains in question became non-encapsulated either by mutation of that gene which determines capsular antigenic specificity, or by mutation of a second gene so closely linked to the first that in transformation reactions both genes travel together. However, Griffith (1928) observed non-encapsulated pneumococcal mutants which might either regain capsules of the antigenic type of their ancestors, or acquire capsules of the antigenic type of the donor strain, a situation analogous to that which we have found in certain $O$ strains which when they acquire flagellation by transduction sometimes but not always acquire also an $\mathrm{H}$ antigen from the donor strain.

In both groups it is in general only possible to transfer one character at a time to any individual cell. The simultaneous transduction of two flagellar characters in salmonellas reported above has, however, a parallel in the simultaneous transference of two separable capsular antigenic characters in H. influenzae (Leidy, Hahn \& Alexander, 1953). Certain observations on allogenic transformation in type III pneumococci led Ephrussi-Taylor $(1951 a, b)$ to postulate that the genetic agent involved in 'type transformation' was spatially differentiated, so that either the whole agent might be transferred, or one part of it only might replace the homologous part in a corresponding agent present in the recipient cell.

Thus the genetic aspects of the phenomena in Salmonella spp., and in pneumococci and $\boldsymbol{H}$. influenzae resemble one another even in the exceptional occurrence of simultaneous transfer of two characters. There seem to be no experimental data incompatible with the view that the genetic particles concerned in the two groups are of the same kind, and that the differences between the phenomena result from the fact that in salmonellas the fragments of genetic material can only be effectively transferred from cell to cell by their association with phage particles.

The work of one of the authors (B.A.D.S.) was in part undertaken during the tenure of a Commonwealth Fund Fellowship. The work at Madison has been supported by grants (E72-C4) from the National Microbiological Institute of the National Institute of Health, U.S. Public Health Service, from the Rockefeller Foundation and from the Research Committee of the Graduate School from funds supplied by the Wisconsin Alumni Research Foundation. This paper is recorded as no. 516 from the Department of Genetics, University of Wisconsin.

We are indebted to Dr P. R. Edwards and Dr J. Taylor for the serological examination of many strains, to Dr A. Felix, F.R.S., and to Dr E. S. Anderson for phage-typing, to Brig. J. S. K. Boyd, F.R.S., for determinations of lysogenicity, and to them and Dr F. Kauffinann, Dr N. A. Boulgakov, Dr K. Lilleengen, Dr E. Leifson, Dr S. T. Cowan, Lt.-Col. H. J. Bensted and Dr N. Datta for the generous provision of cultures, phages and sera.

\section{REFERENCES}

Alexander, H E. \& Leidy, G. (1951). Determination of inherited traits of $\boldsymbol{H}$. influenzae by desoxyribonucleic acid fractions isolated from type-specific cells. J. exp. Med. 93, 345.

ANDrewEs, F. W. (1922). Studies in group-agglutination. I. The Salmonella group and its antigenic structure. J. Path. Bact. 25, 505.

ANDREWEs, F. W. (1925). Studies in group agglutination. II. The absorption of agglutinin in the diphasic salmonellas. J. Path. Bact. 28, 345. 
Avery, O. T., Macleod, C. M. \& McCarty, M. (1944). Studies on the chemical nature of the substance inducing transformation of pneumococcal types. J. exp. Med. 79, 137.

Boyd, J. S. K. (1950). The symbiotic bacteriophages of Salmonella typhi-murium. J. Path. Bact. 62, 501.

BoYd, J. S. K. (1951). 'Excessive dose' phenomenon in virus infections. Nature, Lond. 167, 1061.

Boyd, J. S. K., Parker, M. T. \& MaIr, N. S. (1951). Symbiotic bacteriophage as a 'Marker' in the identification of strains of Salmonella typhi-murium. J. Hyg., Camb. 49, 442.

Braun, H. (1918). Das Wesen der Weil-Felix'schen Reaktion auf Fleckfieber. Berl. klin. Wschr. 55, 637.

Colquhoun, D. B. \& Krrkpatrick, J. (1932). The isolation of motile organisms from apparently non-motile cultures of $B$. typhosus, B. proteus, B. pestis, B. melitensis, etc. J. Path. Bact. 35, 367.

DE HAAN, H. (1933). Inheritance of chlorophyll deficiencies. Bibliogr. genet. 10, 357.

Edwards, P. R. \& Bruner, D. W. (1942). Serological identification of Salmonella cultures. Circ. Ky agric. Exp. Sta. no. 54.

Edwards, P. R. \& Bruner, D. W. (1946). Notes on monophasic Salmonella cultures and their use in the production of diagnostic serums. J. Bact. $52,493$.

Edwards, P. R., Moran, A. B. \& Bruner, D. W. (1946). Flagella and flagellar antigens in 'non-motile' Salmonella cultures. Proc. Soc. exp. Biol., N.Y., 62, 296.

Ephrussi-Taylor, H. (1951 a). Transformations allogènes du pneumocoque. Exp. Cell Res. 2, 589.

Ephrusst-Taylor, H. (1951 b). Genetic aspects of transformations of pneumococci. Cold Spr. Harb. Symp. quant. Biol. 16, 445.

FeLIX, A. (1930). The qualitative serum diagnosis of enteric fevers. Lancet, i, 505.

Feux, A. (1951). Laboratory control of the enteric fevers. Brit. med. Bull. 7, 153.

Feurx, A. (1952a). The Vi antigen of Salmonella paratyphi-A. J. Hyg., Camb. 50, 540.

Felix, A. (1952b). The Vi antigen of Salmonella paratyphi-B. J. Hyg., Camb. 50, 550.

Feurx, A. \& Cancow, B. R. (1943). Typing of paratyphoid-B bacilli by means of Vi bacteriophage. Brit. med. J. ii, $12 \%$.

Felix, A. \& Callow, B. R. (1951). Paratyphoid-B Vi-phage Typing. Lancet, ii, 10.

Feurx, A. \& PITT, R. M. (1951). The pathogenic and immunogenic activities of Salmonella typhi in relation to its antigenic constituents. J. Hyg., Camb. 49, 92.

Friewer, F. I. \& Leifson, E. (1952). Non-motile flagellated variants of Salmonella typhi-murium. J. Path. Bact. 64, 223.

GriffTTH, F. (1928). The significance of pneumococcal types. J. Hyg., Camb. 27, 113.

Hrrsch, W. (1947). A new bacterial variant: the non-motile H form. J. Hyg., Camb. 45,417 .

KaufFmann, F. (1934). Utber serologische und kulturelle Variant Paratyphus-B und Mäusetyphus-Bacillen. Z. Hyg. Infekt-Kr. 116, 368.

Kaufrmann, F. (1989). Die serologische Salmonella-diagnose. Acta path. microbiol. scand. 16, 417.

KaUfFManN, F. (1947). On the serology of the Salmonella V antigen. Acta path. microbiol. scand. 24, 591.

Kauffmann, F. (1951). Enterobacteriaceae. Copenhagen: Einar Munksgaard.

Laderbeng, E. M. (1952). Allelic relationships and reverse mutation in Escherichia coli. Genetics, 37, 649. 
LEDERBERG, J., LeDERBERG, E. M., ZiNDER, N. D. \& Lively, E. R. (1951). Recombination analysis of bacterial heredity. Cold Spr. Harb. Symp. quant. Biol. 16, 413.

LeIDy, G., Hahn, E. \& Alexander, H. E. (1953). In vitro production of new types of Haemophilus influenzae. J. exp. Med. 97, 467.

LEwIN, R. A. (1952). Ultraviolet induced mutations in Chlamydomonas moerousii Gerloff. J. gen. Microbiol, 6, 233.

LILLEengen, K. (1948). Typing of Salmonella typhi-murium by means of bacteriophage. Acta path. microbiol. scand. Suppl. 77.

LwoFf, A. (1953). The nature of phage reproduction. In The Nature of Virus Multiplication. Symp. Soc. gen. Microbiol. 1952. p. 149.

Salmonella Sub-Commitree (1949). Third report of the Salmonella sub-committee of the Nomenclature Committee. Congr. int. Microbiol. (Copenhagen, 1947), p. 617 .

Scrürze, H. (1930). The importance of somatic antigen in the production of Aertrycke and Gaertner immunity in mice. Brit. J. exp. Path. 11, 34.

Sertic, V. \& Boulgakov, N. A. (1936). Bactériophages specifiques pour des variétes bactériennes flagellées. C.R. Soc. Biol., Paris, 123, 887.

Stocker, B. A. D. (1949). Measurements of rate of mutation of flagellar antigenic phase in Salmonella typhimurium. J. Hyg., Camb. 47, 398.

ZiNDER, N. D. \& LEDERBERG, J. (1952). Genetic exchange in Salmonella. J. Bact. 64, 679 .

\section{EXPLANATION OF PLATES}

Cultures on semi-solid medium in $5 \mathrm{~cm}$. diameter Petri dishes, photographed by oblique transmitted light. To enhance the visibility of swarms, the plates after primary incubation at $3^{\circ}$ have been re-incubated at $23^{\circ}$; at this temperature growth continues, but further spreading is prevented by solidification of the medium.

\section{Plate 1}

Fig. 1. Growth confined to sites of inoculation. $O$ strain SW 548, untreated, incubated at $87^{\circ}$ for $48 \mathrm{hr} . \times 1$.

Fig. 2. O strain SW 545, untreated, incubated at $37^{\circ}$ for $18 \mathrm{hr}$., showing discrete colonies at a distance from site of inoculation. $\times 5$.

Fig. 8. Swarm with flare; non-motile $H$ strain SW 578 treated with a lysate of strain SW 580 and incubated at $37^{\circ}$ for $10 \mathrm{hr}$. (The appearance of discrete colonies at the periphery of the swarm is an artifact resulting from secondary incubation.) $\times 5$.

Fig. 4. Continuous border of swarming; $O$ strain SW548 treated with a lysate of strain TM2 and incubated at $37^{\circ}$ for $10 \mathrm{hr}$. $\times 1$.

Fig. 5. Discrete swarms; as Fig. 4 but treated cells diluted 1 in 10 before inoculation. $\times 1$.

Fig. 6. Confluent swarms and trails; $O$ strain SW541 treated with a lysate of strain TM2 and incubated at $37^{\circ}$ for $18 \mathrm{hr}$. $\times 1$.

Plate 2

Fig. 7. A single trail; as Fig. 6, but treated cells diluted 1 in 30 before inoculation. $\times 5$.

Fig. 8. Slow-spreading swarms; strain SW544 treated with a lysate of strain TM2 and incubated at $37^{\circ}$ for $10 \mathrm{hr} . \times 1$.

Fig. ' 9 . Slow-spreading mutant of strain SW 544, untreated, incubated at $37^{\circ}$ for $10 \mathrm{hr}$. One rapid-spreading (mutative) swarm is visible. $\times 1$.

Fig. 10. O strain SW 548 treated with a lysate of strain SW 544 and incubated at $37^{\circ}$ for $10 \mathrm{hr}$. Three fast-spreading and three slow-spreading swarms (indicated by arrows) are visible. $\times 1$.

(Received 18 May 1953) 